it diminished :ill, on the tenth day, no cough followed the in jection.

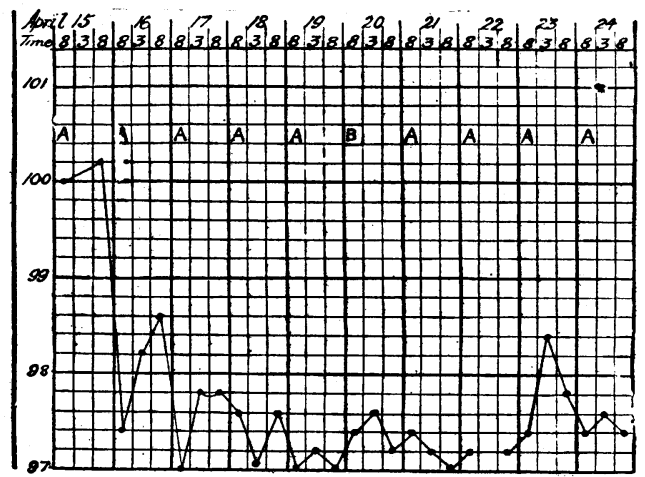

A, Injection of $\mathrm{CHl}_{3}, \mathrm{gr}$. j. $\quad$ B, Injection of $\mathrm{CHl}_{3}$, gr. jss.

Pari passu with these changes there was a progressive sense of betterment and return to health. He felt less exhansted after the congh and his appetite improved. As I have said, the application of this treatment, even by the most dextrous, is quite impossible in children. Their veins, as a rule, are too sniall, even for the finest needles made, and are frequently buried in fat. Besides, very few young children could be coaxed into submitting to the daily prick of a needle, after having a handkerchief tourniquet applied to the arm, or hold the arm steady enough even if they would.

During the past nine.ycars, since I first published this method for treating pulmonary tubercle, I have heard indirectly of alarming symptoms being attributed to the intravenous injection of iodoform. It is rather extraordinary that $I$ should have practised it without intermission for nearly twelve years, and in that time given thousand of injections and never once met with anything worse than a local thrombosis in my earlier experience, which was due to my own want of skill. As icdoform is a power for good in such a complex disease as pulmonary tubercle, ${ }^{1}$ and is apparently potent in pneumonia, persistent pulmonary catarrh, and whooping-cough, it is desirable that the minds of the profession should be disabused on this point. Even in advanced pulmonary tuberculosis patients can stand the continued exhibition of iodoform intravenously without any outward effect. I have shown what it can do in an adolescent with whooping-cough, and I have no hesitation in saying that an adult or eleerly person who contracts the disease will suffer infinitely less from the daily dose of iodoform for ten days or a fortnight (should it be necessary so long) than their hearts and blood vessels will suffer from the strain of repeated prolonged coughing.

In this case the veins were large and well filled, and as I knew the course of treatment if successful would be short, I used 1 grain of iodoform dissolved in 10 minims of methylated ether, specific gravity 0.720 , alone. In a paper in the British Medical Journal for 1905 I advised the addition of as much as 40 per cent. of liquid paraffin in the treatment of pulmonary tubercle, but I now think the less one can work with the better. There is no doubt that the large percentage obviates all risk of iodoform blocking in the needle or jamming the piston of the syringe, and it also greatly diminishes the irritating effect of the ether on the lining membrane of the veins. Where the veins are small, few in number, or badly filled with blood, it must be used in proportions varying from $2 \frac{1}{2}$ to 20 per cent., but it undoubtedly aggravates the coughing at the time, and is more apt to cause breathlessness afterwards than iodoform in ether alone, or with only a very small percentage of paraftin. In all the years I have used iodoform intravenously $I$ have seldom met with any symptoms suggestive of idiosyncrasy, and certainly none pointing to anaphylaxis. Dr. Emery, in his paper on anaphylaxis at the Annual Meeting of the British Medical Association, 1911, alluded to this, not $I$ think as a personal observation, but as having been recorded by Brucks and Klausner. ${ }^{2}$ It is alleged that the shock which sometimes accompanies acute attacks of "serum disease" can be entirely controlled by: the administration of ether as a general anaesthetic. Assum. ing Brucks and Klausner to be right, is it permissible to believe that the ether in the iodoform solution prevents this? I would also add that I have never mec with symptoms of iodoform poisoning.

My object in publishing notes of this case of whoopingcough is not so much to present what looks like a specific treatment (for, as I have said, its application is circum scribed to adolescents and adults) as to direct attention to the general applicability of iodoform administered intravenously in a variety of pulmonary infections occasioned by different specific infections. Nor is its beneficial effect confined to the lungs alone. In a letter I received last month from Dr. W. Johnson Calder, of Rayton, Transvaal, he says: "I am convinced that not only is the injection of use in phthisis, but in pneumonia, asthma, and leprosy, as well as syphilis. This has been my observation, and you should note it."

In these days of vaccine and serum therapy, when a specific infection, we arc led to believe by some, can only be controlled by a particular vaccine or serum, is it not possible to think that chemiotherapy may after all have been thrown over too sion? In the field of established and active disease no inconsiderable successes may yet await it.

1 Dr. Bain, Glasgow Meatical Journances. 1 Dr. Bain, Glasgcw Mectical Journal, 1909; Dr. Crofton, BRITISH
MvDICAL JodR AL, 1912. 2 Berl. Klin. Woch, 1910; Munchener, 1910.

\section{THE CONTAGIOUSNESS OF LEPROSY.}

BY

\section{J. W. LINDSAY, M.B.}

BHLLEN, PARAGUAY, SOUTH MMERICA.

As the perennial discussion of the contagiousness of leprosy appears to have started again, as seen from the correspondence in your issues of March 23rd and 30th and April 20 th, I have thought it might be interesting if I gave the history of various leper families resident in this Republic of Paraiguay.

$I$ daresay medical men resident in leper countries are as a rule so thoroughly convinced of the contagiousness of leprosy that they do not think it worth while to write to contradict statements made to the contrary. After an experience of twelve years in a leper country I am able, from personal observation, to support the view of your correspondent of April 20th, to the effect that "leprosy is nat hereditary," and that "leprosy is contagious." Whether it is spread (as he says) wholly and solely by contagion, immediate or mediate, or whether cases may arise de novo from eating fish or other foods badly cured, is a difficult matter to decide. My own idea of the question will be gathered from what follows.

It is almost certain that for the rapid spread of leprosy in a country certain favourable conditions are necessary. It may be, as the advocates of the fish theory hold, that the conditions necessary are those of diet-that leprosy has been most prevalent when a certain kind of diet has been in general use.

At the present time in Paraguay leprosy is spreading like wildfire. Daring the last ten years the number of lepers has doubled-perhaps even trebled. In that time there has been no change in the mode of living of the people as regards their diet.

At the present time leprosy is far more contagious in Paragnay than tuberculous disease of the lungs. I could give various instances of phthisical patients who have lived in the midst of their families in their little windowless huts, have expectoratod over floor and walls or wherever convenient, and yet their families, husbands or wives or children, have not contracted the disease as far as can be seen. A man in a house not a square from here is in tho last stages of phthisis. His wife and two children have slept in the same room and eaten with the patient now for six years. Not one of the family shows a sign of phthisis. Signs may appear later; but what I wish to show is that tuberculosis has not found a suitable home in this country such as it has in Great Britain. Far otherwise is it with leprosy.

Ten years ago I first saw A. M. He had a black patch covering the place where his nose had been. He was in the last stage of leprosy. Two years later I was called to atten his son, who had been stabbed in the chest. The leper father was squatting in a corner of the hut. A year later he died. 
Two vears later his daughter consulted me. I diagnosed leprosi. She is now disfigured with the nodular form of the disease. Two years ago a son of the old leper, brother of the last, consulted me for indefinite symptoms. I suspected leprosy. Now the patient's face has the typical roughness and duskiness of the nodular disease. These two patients had alwars slept in the same room as their father, caten from the same dish, and used the same bombilla, or metal tube for sucking maté.

IR. R. I had known as a leper for many years. Three years ago I saved his face from being caten away by maggots by destroyins the latter with powdered calomel. Last year R. R. died of preumonia. In the same room lived his wife and grown-up family. To-day his danghter, aged 25, came to consult me. 'Three months ago I had seen her and had noticed nothing in her appearance. 'I'o-day the expression of her face made me look twice. It was roughened with nodules and discoloured. She showed me her shoulders, and they presented a typical leprous eruption. She had come to consult me about another trouble, and asked me, by the way, if I conld give her some melicine for her brother, who was worrying about a skin disease that had appeared on his shoulders, "the same as this on mine," she added, as she bared her own shoulder. The son and daughter had lived in close proximity to their father all their lives, and have contracted his disease.

A European, C. D., had been known as a leper for many vous. Twelve vears ago I became acquainted with him. He vas then a trpical leper with leonine face. He went on a visit to Furope. In $H$. he consulted a doctor about his eves. The to turope. In $H$. he consulted a doctor about his eyes. The loctor diagnosed his leprosy and scemed scared. His remarks embrried again for South America on the first steamer. In Bucnos Aires he consulted a doctor about his eves. The doctor got a shock, which he unconsciously communicated to C. D., got a shock, which he unconsciously communicated to C. D., the pleasure of reading in a European paper of a mysterious case of leprosy that bad been seen in $H$. in such an advanced stage that the medical man had reported it to the authorities. When the anthorities came to look for C. D. he had disappeared. He was a very nice old man, and I had him brought out to our village and placed in a small isolated house. He lived there for about nime months and then died. The nearest native housc was about fifteen yards from where $C$. D. lived and died. The native was M. (Q., and he used to sit with C. D., and even share lis meals. his meals. The day that ( D. died, and before we could get fir burient ficis his: witch and sulter the about a sealiness of his ears. He is now a confirmed cper. For throe young family; theu he wert to live in a hut in his plantation. Within the last three years three of his laughters, aged 20, 15, and 12
have become lejers. Within the last two vears the children of have become lepers. Within the last two vears the children of

yards from M's. there are three leper children. Six years ago I had occasion to visit an old man and his wife in connexion with a matter of btisiness. Medical certificates of their state of health were required in a legal casc. I found that they were loth lepers. Two years previously a daughter of theirs had consulted me for hicart trouble. She suffered from brathlessness and palpitation. Her pulse was genelally between 120 and 140. I coult find no caltse for the rapid heart action. I tried various remedies, but after some months she left cff taking medicines as they did her no good. When I saw her father and mother were leper's 1 immediatcly asked for her. Her parents laughed and said that she was hicking in the honse as she had grown so ugly! I called her out; her face was horribly disfigured with tubercular leprosy. I came to the conclusion that the tachycardia that had puzzled me rears before had been due to a very severe invasion of the lepra bacillus. The case developed very rapidly. 'The patient had lived with her parents, eaten with them and slept with them, and had become a leper.

M. C , a woman, has been a leper for some years. She lived in the house of her sister, R. C., who had a young family. When $M$. C. began to get disfigured in the face she went to live in another part. R. C's. oldest boy of 13 is now a typical leper, and his younger brothers are all attacked by the disease, a fact thai can be considered certe
will vield to no treatment.

From these cases and from the histories of many others that I might quote I am absolutely convinced that in this country at any rate leprosy is spread by contagion, either immediate throigh contact with a leper or his discharges, or mediate through conveyance of the infection by inseats. In this country also there is no doubt that, owing to the conditions being so favourable to the rapid sprcad of leprosy, the disease is far more infectious than is tuberculons disease of the lungs, for which the conditions are not so favourable. It may be also that the presont invasion of l prosy is due to a a more than usually virulent strain of the bacillus. It has nothing at all to do with fisl-eating, as the prople do not cat fish, and although they are all Roman Catholics, the only Friday when they do not eat moat is Good Friday!

Your correspondent of April 20th says : "As I have lived and worked in a very large leper asylum for nearly seven years, and am in consequence myself a leper," as if to imply that such a fate was inevitable-and I quite agrec with him. In this country, with the virulent type of leprosy at present so rapidly spreading, it would bc almost impossible for a medical man to do his duty to his leprous patients in a leper asylum (if such existed) and escape infection.

Your correspondent mentions a curious point: "Witl regard to myself, I am not at present contagious."' How does he know? Perliaps the most contagious stage of leprosy is before any outward signs are visible, and when children and relatives and the paticnt himself have no idea of danger. When outward visible-signs appear I fancy it may then be too late to think of separating from one's family with the idea of saving them from the discasc.

Two days ago a typical tubercular leper came to my dispensary. His face and his hands were greatly disfigured. Fonr vears ago he had gone to a general hospital in. the capital, Asuncion, to consult about his nose. Years before he hal hal

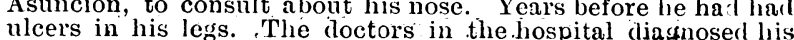
case as syphilis and treated him with in jections of varions kinds case as syphilis and treatcd him with in jections of varions kinds
for four months. He then had a peculiar dryness in his nose, for four months. He then had a peculiar dryness in his nose,
which on occasion would also get stuffed up. It probably had which on occasion would also get stuffed up. It probably harl
been the first lesion of his leprosy. For three years he lives been the first lesion of his leprosy. For three years he livesl
with his family and worked with other men with the scarcely noticeable leprous lesion in his nose, and only six months ago did any other symptom appear, and then his hands and face began to. swell, and to-day the diagnosis is unmistakable.

The diagnosis at the beginning, and perhaps for many years, is extremely difficult, in many cases, but in leper countries medical men very often can diagnose with certainty even. incipient cases. The sanitary board in tho capital has very strict regulations regarding lepers, their isolation, their non-admission to public buildings and public conveyances, etc., but the regulations are a dear letter, and nobody seems to mind where the lepers go or what they do. Up to the present it has been impossible to cnforce the law for their isolation. When compulsory isolation becomes possible in this country, then we may hope that the disease will be checked and in time stamped out.

\section{STRANGLLATED INGUINAL HERNIA IN AN} INFANT.

By G. E. E. NICHOLLS, M.B., Сн.B.Vict., CroYDON:

Thovgr there is no point of an unusual naturn to bo related in connexion with this case, yet as strangulation at so early an age as eight weeks is by no mcans common the report may not be without interest to many.

A male child, born on March 16th, 1912, had becn circumcised on April 4th owing to marked phimosis.

On the evening of May 12th, the child being then eight weeks old, I was called in as it had been crying almost continuously since mid.?ay, he was also said to have vomited twice during the afternoon; this was not altogether remarkable as there had been considerable trouble in feeding for the past two or three weeks. On examination, however, the patient was found to be in a somewhat collapsed state, with very rapid and feeble pulse, and with a pinched and anxious expression. A small firm mass was found on the right side of the scrotum, obviously produced by a right inguinal hernia.

A careful attcmpt at reduction under an anaesthetic proving useless, I decided to operate at once. The hernia consisted of a knuckle of small intestine; it was oedematons and of a dark purple colour, but the serous coat was not without lustre, and it might evidently be replaced with safety. The sac contained about a drachm and a half of palc clear fluid. The constriction was at the internal ring, and there was some difficulty in returning the gut, the ring having to be incised in one or two places. The sac was of the complete funicular" (so-called "congenital") type, the testis being found within it at the lower end. The sac was ligated high up, and two buried sutures inserted to diminish the size of the external ring. Recovery was complete and uneventful.

This was apparently the first occasion on which tho hernia bad come down, and the antecedent gastric disturb. ance, involving repeated vomiting and consequent raised intra-abdominal pressure, may no doubt have been a factor in the pioduction of the hernia. There was no suppression or retention of urine, as has often been noted in these cas?s of strangulation in infancy. 